\title{
POTENSI PENDAFTARAN KRETEK SEBAGAI INDIKASI GEOGRAFIS KABUPATEN KUDUS
}

\author{
Toebagus Galang Windi Pratama ${ }^{1}$, Kholis Roisah² \\ Program Studi Magister IImu Hukum \\ Fakultas Hukum Universitas Diponegoro \\ r_kholis@yahoo.com
}

\begin{abstract}
ABSTRAK
Kretek adalah salah satu budaya Indonesia yang berasal dari Kudus. Walaupun Kretek dikucilkan karena stigma kesehatan namun Kretek memiliki potensi ekonomi tinggi dan karakteristik yang khas sehingga berpotensi menjadi produk indikasi geografis. Pokok Permasalahan yang dikaji ialah apakah Rokok Kretek berpotensi untuk dilindungi sebagai produk Indikasi Geografis Kabupaten Kudus dan bagaimana implikasi Perlindungan Terhadap Kretek. Hasil penelitian menunjukan bahwa Kretek memungkinkan menjadi produk Indikasi Geografis karena memenuhi persyaratan yang dipersyaratkan berdasarkan Undang Undang Nomor 15 Tahun 2001 Tentang Merek dan PP Nomor 51 Tahun 2007 Tentang Indikasi geografis yang dalam perkembangannya dimungkinkan juga menjadi Indikasi Geografis nasional atau bahkan Warisan Budaya Indonesia. Perlindungan Kretek sebagai Indikasi Geografis Kudus menimbulkan Implikasi Positif baik pada bidang ekonomi seperti meningkatnya pemasukan negara dan penyerapan tenaga kerja, di bidang sosial dimana dapat meluruskan stigma negatif Kretek, dan juga di bidang hukum dimana dapat dijadikan Referensi bagi hasil industri lainnya untuk menjadi produk Indikasi Geografis dengan catatan tidak menganggu kesehatan maupun hak orang lain sehingga pengaturan ruang khusus merokok dan larangan pada ibu hamil dan anak dibawah umur tetap harus ditegakkan.
\end{abstract}

Kata Kunci: Indikasi Geografis; Kabupaten Kudus; Kretek; Pendaftaran; Potensi

${ }_{1}$ Dosen Fakultas Hukum Universitas PGRI Semarang, J I. Sidodadi Timur Nomor 24 - Dr. Cipto Semarang

2 Penulis Kedua, Penulis Koresponden 


\section{PENDAHULUAN}

Potensi bahwa Rokok Kretek dapat menjadi Indikasi Geografis bukanlah suatu hal yang tidak mungkin sama halnya dengan cerutu Kuba dan tembakau Turki. ${ }^{3} \mathrm{Hal}$ ini dikarenakan walaupun tembakau berasal dari Amerika namun seiring perkembangan jaman, tembakau yang mulai di budidayakan di negara masing masing mulai memiliki ciri khas yang berbeda satu sama lain. Cita rasa Kretek Kudus yang tidak hanya berupa tembakau namun juga dicampur dengan cengkeh dan saus tertentu tentunya memiliki citarasa yang berbeda dengan Rokok dari daerah lain ${ }^{4}$.

Rokok Kretek memiliki sejarah yang panjang, sejak diperkenalkan oleh bangsa Portugis, ia sudah berakar ke dalam kebudayaan bangsa dan keberadaannya sulit tergantikan namun seiring dengan berkembangan jaman terlebih di era globalisasi ini merokok menjadi suatu hal yang tabu. Dikatakan demikian, karena banyak penelitian medis yang mengungkapkan tentang bahaya merokok baik pada perokok secara aktif yakni yang menghisap langsung dan perokok pasif atau yang menghisap secara tidak langsung, tanpa memandang kontribusi besar yang diberikan oleh industri Rokok pada negara. Pada Tahun 2013, perusahaan Rokok besar seperti Sampoerna

\footnotetext{
${ }^{3}$ Melissa Brockley, TED Case Studies Number760, 2004 Pada Http://www1.American.Edu/Ted/Turkish-Tobacco.Html Diakses Pada 14/08/2015.

${ }^{4}$ G.C. Clark (1989). "Comparison Of The Inhalation Toxicity Of Kretek (Clove Cigarette) Smoke With That Of American Cigarette Smoke. I. One Day Exposure". Archives of Toxicology 63 (1): 1-6
}

menyumbangkan cukai sejumlah Rp 30,7 triliun. Kontribusi tercatat sebesar $29,6 \%$ dari total pendapatan domestik cukai produk tembakau negara sebesar Rp103,6 triliun pada Tahun 2013 berdasarkan Nota Keuangan dan Rancangan Anggaran Pendapatan dan Belanja Negara Tahun 2015.5

Perlindungan terhadap Kretek juga bisa dikatakan sebagai suatu urgensi karena betapapun dunia mengucilkan Kretek seperti di Amerika yang melarang Kretek masuk sebagaimana tercantum dalam Family Smoking Prevention And Tobacco Control Act 2009, produk ini ternyata dilirik oleh dunia internasional karena potensi ekonominya seperti yang dilakukan oleh Phillip Morris International yang memproduksi Marlboro Kretek Mint yang diluncurkan di Meksiko. ${ }^{6}$ Fakta ini tentu mengkhawatirkan karena hingga saat ini Kretek masih belum mendapat perlindungan yang kuat dari pemerintah.

Indikasi Geografis menurut Penulis merupakan salah satu wujud perlindungan Intellectual Property Rights ${ }^{7}$ yang ideal selain perlindungan sebagai warisan budaya, karena hak kekayaan intelektual ini lebih bersifat komunal, atau bukan milik perseorangan melainkan milik sekelompok orang pada daerah tertentu.

\footnotetext{
5http://Www.Sampoerna.Com/ld_Id/Tobacco_Regulation/Pag es/Tobacco_Taxation_System_In_Indonesia.Aspx Diakses Pada 14/08/2015

${ }^{6} \mathrm{Http}: / /$ Www.Pmi.Com/Eng/Our_Products/Pages/Our_Brands. Aspx Diakses Pada 24 November 2015

7 Bambang Kesowo, Posisi Dan Arti Penting KI Dalam

Perdagangan Internasional, Hal 3 ; Jakarta, 2007
} 
Keberadaannya diatur dalam Undang Undang Merek Nomor 15 Tahun 2001 Pasal 56, 57 dan 58. Walaupun keberadaannya diatur dalam Undang Undang yang sama dengan merek tidak lantas disamakan antara merek dengan Indikasi Geografis, karena sifat kepemilikan Merek adalah individual.

Indikasi geografis, berdasarkan Pasal 56 UU merek nomor 15 Tahun 2001 ialah suatu tanda yang menunjukkan daerah asal suatu barang, yang karena faktor lingkungan geografis termasuk lingkungan alam, faktor manusia, dan kombinasi dari kedua faktor tersebut, memberikan ciri dan kualitas tertentu pada barang yang dihasilkan. Berdasarkan definisi Indikasi Geografis ini, Kretek dimungkinkan menjadi produk Indikasi Geografis karena erat dengan Faktor Manusia sebagaimana yang disebutkan dalam definisi tersebut.

Gagasan Indikasi Geografis terhadap Rokok Kretek Kabupaten Kudus tentunya menimbulkan kontroversi karena Rokok sering dipandang negatif karena Implikasinya yang buruk bagi kesehatan, padahal banyak negara berlomba untuk mendaftarkan Indikasi Geografis atas olahan tembakaunya seperti Kuba dan Turki terlebih dalam menghadapi persaingan ekonomi yang semakin ketat tentunya sektor industri yang memiliki kontribusi besar sudah sewajarnya diperhatikan dan didukung. Maka dari itu, penulis merasa tertarik untuk membahasnya dengan Pokok Permasalahan :
1. Apakah Produk Rokok Kretek Di Kabupaten Kudus Berpotensi Untuk Dapat Dilindungi Sebagai Indikasi Geografis ?

2. Bagaimana Implikasi Perlindungan Hukum Terhadap Rokok Kretek Sebagai Indikasi Geografis Kabupaten Kudus?

\section{METODE PENELITIAN}

Metode Penelitian yang digunakan adalah Yuridis Empiris dengan spesifikasi penelitian yang bersifat bersifat deskriptif analitis ${ }^{8}$ yaitu pemecahan masalah yang diselidiki dengan menggambarkan keadaan obyek penelitian pada saat sekarang, berdasarkan fakta-fakta yang tampak atau sebagaimana adanya. penelitian ini merupakan penelitian yang yang bertumpu pada data yang didapat dengan Teknik pengumpulan data menggunakan metode Wawancara di Komunitas Kretek, Kemenkumham Jawa Tengah, PPRK Kudus dan Pemkab Kudus sebagai data primer yang dianalisis mengunakan data literatur dan peraturan perundang undangan yang berlaku sebagai data sekunder.

\section{KERANGKA TEORI}

Pokok permasalahan pertama yang dibahas penulis yakni apakah bisa Rokok Kretek dilindungi sebagai Indikasi Geografis Kabupaten Kudus, akan penulis analisis dengan berpegangan pada teori dari Lawrence M. Friedman tentang Tiga Unsur

\footnotetext{
8 Hadari Nawawi \& Mimi Martini, Penelitian Terapan, Hal 73 ; Yogyakarta: 1994.
} 
Sistem Hukum ${ }^{9}$ sebagai teori utama dalam menganalisis disertai teori teori relevan lainnya sebagai pendukung dan teori dari Richard A. Posner tentang Economic Analysis Of Law 10 sebagai teori utama dalam menganalisis pokok permasalahan kedua yakni Implikasi yang ditimbulkan apabila Rokok Kretek menjadi Indikasi Geografis Kabupaten Kudus yang tentunya dari segi ekonomi dan didukung dengan teori teori lainnya yang relevan seperti teori las as a social engineering Roscoe Pound ${ }^{11}$ yang akan dijabarkan pada pembahasan.

\section{PEMBAHASAN}

\section{A.Potensi Perlindungan Kretek Sebagai Indikasi}

\section{Geografis Kudus}

Rokok ialah silinder dari kertas berukuran panjang antara 70 hingga $120 \mathrm{~mm}$ (bervariasi tergantung negara) dengan diameter sekitar 10 $\mathrm{mm}$ yang berisi daun-daun tembakau yang telah dicacah. Rokok dibakar pada salah satu ujungnya dan dibiarkan membara agar asapnya dapat dihirup lewat mulut pada ujung lainnya. Rokok biasanya dijual dalam bungkusan berbentuk kotak atau kemasan kertas yang dapat dimasukkan dengan mudah ke dalam

\footnotetext{
${ }^{9}$ Lawrence Friedman, American Law, Hal 6 ; W.W Norton \& Company, London, 1994.

10 Richard Posner, Dalam Sanders, Anthony, Posner, Hayek $\&$ The Economic Analysis Of Law, Paper, Hal 1 ; Geogre Mason University, Virginia, 2003.

11 Roscoe Pound, Dalam Atmadja, Edi, Artikel, Hukum Sebagai Sarana Rekayasa Sosial, Radar Lampung, 30 Mei 2012.
}

kantong. Kebiasaan mengkonsumsi tembakau dengan cara digunakan sebagai Rokok konon berasal dari benua Amerika sekitar Tahun 600 SM. 12

Rokok Kretek adalah rokok yang menggunakan tembakau asli yang dikeringkan, dipadukan dengan saus cengkeh dan saat dihisap terdengar bunyi Kretek-Kretek. Rokok Kretek berbeda dengan rokok yang menggunakan tembakau buatan maupun rokok berbahan menthol (Rokoknya Orang Barat). Jenis cerutu merupakan simbol Kretek yang luar biasa, semuanya alami tanpa ada campuran apapun, dan pembuatannya tidak bisa menggunakan mesin. Masih memanfaatkan tangan pengrajin. Ulasan tentang sejarah Kretek di Indonesia bermula dari Kabupaten Kudus, Jawa Tengah.

Berdasarkan jenisnya, rokok dibagi dua jenis. Pertama, Kretek non-filter, Kretek jenis ini masih terbagi dari yang Tingwé (kependekan dari bahasa Jawa, Ngelinting Déwé yang berarti melinting sendiri, untuk diartikan sebagai lintingan tangan) tanpa saus tambahan, cerutu, klobot dan lintingan mesin dengan tambahan saus cengkeh. Sedangkan yang kedua adalah Kretek dengan filter berisi semacam gabus yang berfungsi menyaring nikotin dari pembakaran tembakau dan cengkeh.

\footnotetext{
12 Ronald Hutapea, Why Rokok? Tembakau Dan Peradaban Manusia, Hal XV ; Bee Media, Jakarta, 2013.
} 
Penemuan Kretek bermula di kabupaten Kudus pada awal abad 19 oleh haji djamali dan kemudian dipopulerkan oleh nitisemito lewat merek bal tiga pada tahun 1908 dan terus menyebar dan hingga sekarang masih menjadi salah satu ciri khas dari kabupaten Kudus.

Pembuatan Kretek tidaklah sesederhana membuat rokok konvensional yang hanya menggunakan tembakau. Campuran tembakau dengan cengkeh yang diberi campuran saus tertentu membuat Kretek memiliki citarasa yang yang berbeda dengan rokok konvensional dan bahkan antar produk Kretek yang satu dengan produk Kretek yang lain. kerumitan dalam pembuatan Kretek juga bertambah karena sebagian besar Kretek yang diproduksi di Indonesia menggunakan tembakau tembakau domestik yang memiliki kompleksitas rasa dan kualitas yang tinggi. Kompleksitas dan kualitas dari tembakau Indonesia tidak lain karena teknik dalam memanen dan proses pengeringan. Pilihan tembakau yang kaya dalam pembuatan Kretek tak jarang membuat satu merek Kretek menggunakan lebih dari 30 jenis tembakau hanya untuk mendapat citarasa yang diharapkan.

Rokok Kretek merupakan warisan budaya leluhur bangsa Indonesia. Rokok Kretek, semenjak ditemukan hingga sekarang menjadi bagian dari budaya bangsa tidak peduli kontroversi yang muncul. Budaya tersebut dapat di lihat di masyarakat jawa khususnya dimana
Kretek ditawarkan di setiap ada perkumpulan warga, sebagian besar rumah warga juga selalu menyediakan asbak, walaupun pemilik rumah tidak mengkonsumsi.

Rokok Kretek, sama halnya dengan rokok kebanyakan, erat dengan stigma memperburuk kesehatan, padahal tidak sepenuhnya demikian sebagaimana dapat dilihat pada tabel dibawah :

Tabel I

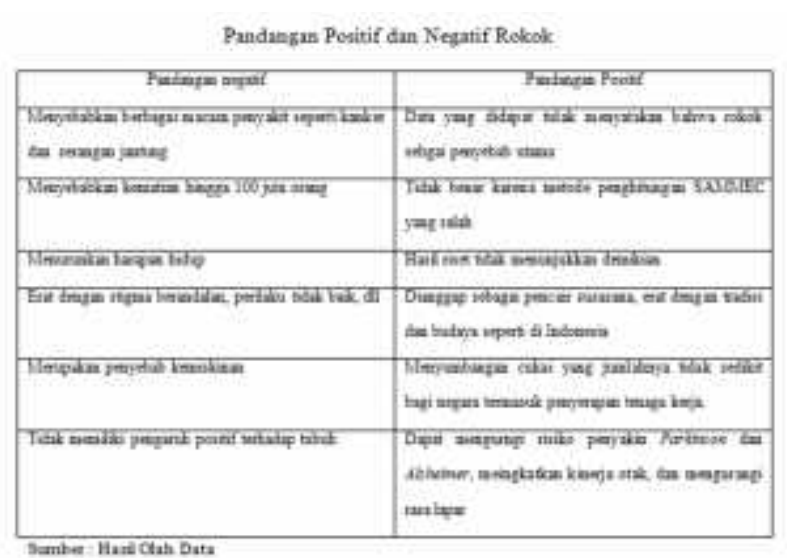

Rokok Kretek, sebagaimana dapat dilihat pada tabel diatas tidak selalu erat dengan stigma negatif sehingga Potensi Kretek sebagai Indikasi Geografis Kabupaten Kudus tidak seharusnya terhalang akan stigma negatif tersebut. kemudian untuk dapat mengetahui seberapa besar potensi Kretek sebagai Produk Indikasi Geografis ialah dengan membandingkan kenyataan yang ada di lapangan dengan persyaratan yang diberikan Undang Undang atau lebih spesifiknya persyaratan dalam pembuatan buku persyaratan sebagaimana diberikan pada Pasal 6 ayat (3) 
Jurnal Law Reform

Volume 12, Nomor 2, Tahun 2016
Program Studi Magister Ilmu Hukum

Fakultas Hukum Universitas Diponegoro
PP Nomor 51 Tahun 2007 dan ketentuan tentang produk yang tidak bisa didaftarkan sebagai produk Indikasi Geografis sebagaimana dapat dilihat pada Pasal 3 PP yang sama, yang kemudian dianalisis menggunakan teori tiga unsur sistem hukum dari Friedman ${ }^{13}$, yakni :.

1. Uraian mengenai karakteristik dan kualitas yang membedakan

Kretek merupakan produk asli Indonesia, ia memiliki karakteristik tersendiri yang membedakannya dengan rokok pada umumnya karena Kretek sudah melalui proses akulturasi dari rokok yang dibawa bangsa asing menjadi salah satu budaya bangsa yang tak tergantikan yang dapat dilihat baik dari segi, sejarah, metode pembuatan, kontrol produksi bahkan teknik pemasaran. Penulis merangkum perbedaan Kretek dengan rokok pada umumnya sebagaimana dapat dilihat pada tabel dibawah :

\section{Tabel II}

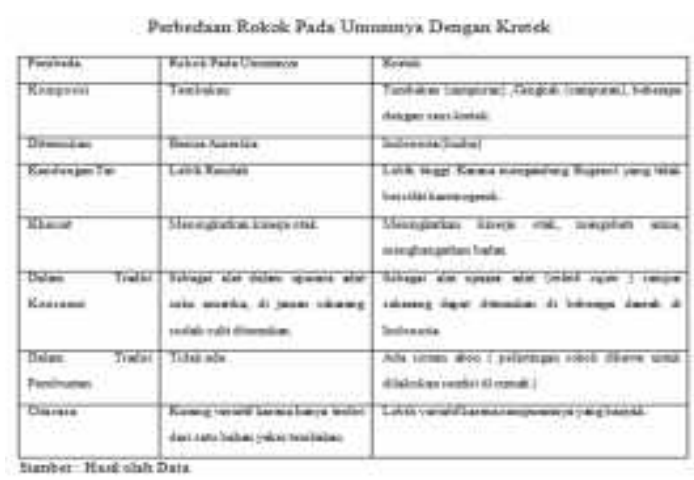

Pengklasifikasikan Kretek memang cukup rumit karena walaupun dapat ditarik

13 Lawrence Friedman, Loc Cit. perbedaan dengan rokok konvensional lainnya bahwa pada dasarnya Kretek merupakan campuran tembakau dan cengkeh pada umumnya dan ada beberapa yang kemudian diberi saus khusus dan dibungkus entah dengan daun jagung, kertas ataupun dau tembakau ia menghasilkan kombinasi yang tak terbatas baik karena kombinasi tembakau yang digunakan, cengkeh, saus dan bahkan pembungkus yang digunakan.

Kerumitan pengklasifikasian Kretek juga pada dasarnya dialami semua produk kerajinan tangan. Dalam Pasal 56 poin (7) disebutkan bahwa Indikasi-geografis terdaftar mendapat perlindungan hukum yang berlangsung selama ciri dan/atau kualitas yang menjadi dasar bagi diberikannya perlindungan atas indikasigeografis tersebut masih ada. Hal ini memberatkan produk Indikasi Geografis yang merupakan hasil kerajinan maupun industi karena letak kekhususan dari produk tersebut adalah manusianya.

Walaupun secara teoretis kerajinan tangan bisa menjadi produk Indikasi Geografis namun Berbeda dengan produk yang bergantung pada faktor alam seperti ubi cilembu misalnya yang hanya tumbuh di daerah pamulihan, sumedang jawa barat yang lekat dengan kondisi geografisnya, sehingga apabila ditanam di tanah lain tidak 
Jurnal Law Reform

Volume 12, Nomor 2, Tahun 2016
Program Studi Magister Ilmu Hukum Fakultas Hukum Universitas Diponegoro akan menghasilkan citarasa seperti madu. Hasil kerajinan dan industri, merupakan produk yang berasal dari kekayaan intelektual manusia sehingga :

1.tidak harus terpaku dengan wilayah.

2.dapat dikreasikan sesuka pembuatnya.

Hasil kerajinan dan industi dalam hal ini, seperti meubel ukir maupun Kretek tidak harus terpaku pada Kabupaten Kudus atau jepara bagi meubel ukir, atau harus menggunakan bahan dari daerah yang sama karena letak kekhususannya ada pada pembuatnya dan ini cukup menyulitkan bagi industri yang berada di luar daerah yang bersangkutan.

Poin kedua, karena letak kekhususan ada pada pembuatnya maka tidak menutup kemungkinan hasil produknya akan terus mengalami perubahan karena faktor faktor tertentu seperti permintaan pasar misalnya.

Kedua dalil yang diungkapkan penulis bahwa kerajinan tangan ataupun hasil industri tidak terpaku pada satu wilayah tertentu dan dapat dikreasikan oleh pembuatnya sehingga berbeda dengan hasil alam, sulit untuk dijadikan indikasi geografis, namun bukan berarti ia tidak dapat mendapat perlindungan atas hak kekayaan intelektual terutama indikasi geografis. Ada beberapa poin yang menjustifikasi hal tersebut.
Hasil kerajinan dan industri memang erat dengan kedua dalil yang disebutkn penulis diatas namun bukan berarti "karakteristik" yang membedakan yang menjadi dasar perlindungannya sebagai hak kekayaan intelektual tidak ada. Seperti Kretek yang memiliki daya pembeda dengan rokok putih ataupun jenis rokok lainnya yang muncul setelah melewati banyak generasi yang membuatnya memiliki reputasi yang tinggi dan hal ini bisa dilihat dari berbagai upaya peniruan Kretek diluar negeri seperti Phillip Morris dengan Marlboro Kretek Mint maka dari tidak hanya Kretek, apabila suatu hasil kerajinan tangan atau industri memiliki reputasi, karakteristik dan potensi ekonomi yang tinggi maka sudah selayaknya ia harus dilindungi dan Indikasi geografis merupakan sebuah langkah yang bagus untuk melindungi produk produk tersebut karena ketentuan yang ada sudah memperbolehkannya.

Berkaitan dengan kedua dalil yang diungkapkan penulis dalam hubungannya dengan Kretek yang menjadi pokok permasalahan dalam tesis ini maka untuk mendukung argumen penulis mengenai bisa tidaknya Kretek, dan juga Hasil industri secara keseluruhan dapat menjadi produk indikasi geografis maka Penulis akan mengambil contoh Meubel Ukir Jepara. Meubel Ukir Jepara merupakan satu satunya 
Jurnal Law Reform

Volume 12, Nomor 2, Tahun 2016
Program Studi Magister Ilmu Hukum Fakultas Hukum Universitas Diponegoro hasil kerajinan tangan yang menjadi produk indikasi geografis di Indonesia yang namun menurut penulis Meubel ukir jepara sudah tidak bisa dikatakan sebagai hasil " kerajinan tangan" karena skala produksinya yang sudah besar ${ }^{14}$ sehingga merupakan hasil Industri karena istilah hasil Industri atau kerajinan tangan sebenarnya hanya merujuk kepada besarnya skala produksi dan tentunya jumlah modal walaupun sebenarnya kerajinan tangan termasuk ke dalam hasil industri sehingga bisa dikatakan bahwa Meubel Ukir Jepara adalah Hasil Industri Kerajinan Tangan. ${ }^{15}$

Meubel Ukir Jepara, sebagaimana yang diungkapkan penulis sebelumnya, apabila dilihat dari gaya ukiran yang menjadi ciri khas meubel ukir jepara tidak memiliki karakteristik yang "khas" sebagaimana dapat dilihat pada buku persyaratan Indikasi Geografis meubel ukir jepara dibawah ${ }^{16}$ :

1. Motif tumbuhan merupakan motif yang paling banyak digunakan, digambarkan dalam bentuk motif yang distilasi, banyak dikomposisikan

14 Data terakhir pada 2006 dimana jumlah produksi mencapai 55.765.736,12 dengan nilai 111.842.200, 42 USD, Sumber Buku Persyaratan Indikasi Geografis Meubel Ukir Jepara, 2010

15 Manufacturing \& Investment Around The World: An International Survey Of Factors Affecting Growth \& Performance, ISR Publications/Google Books, revised second edition, 2001.

${ }^{16}$ Buku Persyaratan Indikasi Geografis Meubel Ukir Jepara, Pemkab Jepara, 2010. dengan motif untaian bunga, atau lunglungan bungan.

2. Motif bergerombol seperti kipas dan terdapat buah dalam jumlah ganjil, kelompok motif daun membentuk prisma segitiga dan setiap daun memiliki tiga ujung tangkai.

3. Arah dan gerak motif tumbuhan menampakkan gerak keseimbangan ke kiri kemudian ke kanan dan seterusnya.

4. Pecahan pada sehelai daun membentuk "sinar", garis garis pada sehelai daun. Mengarah dari bagian tangkai daun ke bagian ujung daun.

5. Hasil pahatannya cekung tipis

6. Lemah, atau dasar ukiran tidak terlalu dalam tetapi ada juga ukiran yang tembus.

7. Komposisi ukiran umumnya simetris.

8. Motif hewan umumnya menggunakan motif burung sebagai bagian dari komposisi motif tumbuhan.

Definisi mengenai ukiran asli jepara tersebut masih terlalu luas karena menggunakan kata "umumnya", "ada juga" sebagaimana pada poin 6,7, dan 8.

Penggunaan kata "umumnya" dan "ada juga" membuat penafsiran atas batasan dari apa itu meubel ukir jepara menjadi rancu.

Hal yang sama juga dijumpai dalam Sistem Indikasi Geografis di India, negara yang sama seperti Indonesia yakni mengakui kerajinan dan hasil industri sebagai Indikasi Geografis apabila dilihat Indikasi Geografis yang berupa hasil Manufacture ( industri ) 
juga tidak memiliki ciri khas yang signifikan seperti Mysore Agarbathi ( dupa ), Coimbatore Wet Grinder ( penggiling basah ), Kannauj Perfume ( parfum ) dan kerajinan kerajinan lain yang juga tidak memiliki ciri khas yang signifikan ${ }^{17}$.

2. Faktor alam dan atau faktor manusia yang merupakan satu kesatuan dalam memberikan pengaruh terhadap kualitas atau karakteristik dari barang yang dihasilkan.

Pembicaraan tentang Kretek sudah tentu erat kaitannya dengan Kudus yang merupakan kabupaten terkecil di Jawa Tengah dengan luas wilayah mencapai 42.516 Ha yang terbagi dalam 9 kecamatan.

Sebutan Kudus sebagai kota Kretek bukan tanpa sebab karena Kretek pertama kali ditemukan di Kudus. Kudus sendiri juga merupakan kota sentral dari 4 kota besar selain Kediri, Surabaya dan Malang yang memproduksi Kretek.

Apa yang menjadikan industri Kretek di Kudus begitu subur ? hal ini karena mengingat jenis tanah yang kurang subur dan luas lahan yang sempit, sektor pertanian di Kudus tidak berkembang seperti banyak daerah lainnya di Jawa. Karena itu --seperti umumnya kabupaten lain di sepanjang

\footnotetext{
${ }^{17}$ Registered GI November 2015 In India,

Http://IpIndia.Nic.In/GirIndia/, Diakses Pada 20 November 2015
}

pesisir utara Pulau Jawa-- maka sektor jasa, perdagangan dan industri justru lebih pesat di Kudus, bahkan sejak masa penjajahan Belanda dahulu. Soekisman (1995) mencatat data sejarah bahwa sejak awal abad-20, sebagian besar petani -terutama buruh tani-di daerah Kudus telah berpindah kerja ke berbagai pabrik yang bermunculan di sana, mulai dari pabrik petasan, lantai tegel dan keramik, es, pengolahan dan industri Kretek ${ }^{18}$.

Industri Kretek yang kemudian berkembang di Kudus ini tentu saja menyerap banyak tenaga kerja yang mendapat keterampilan dalam mengolah Kretek baik dari pemilihan jenis tembakau, cengkeh dan saus yang tidak sembarangan karena butuh banyak pengalaman yang turun temurun.

Setelah mengkaji bagian demi bagian maka penulis dapat menyimpulkan besar potensi Kretek sebagai Indikasi Geografis melalui pointer diatas yang kemudian dianalisis menggunakan teori 3 unsur sistem hukum Friedman sebagai berikut :

Apabila dilihat dari segi substansi, walaupun apabila dilihat dari pengaturan Indikasi Geografis semata Kretek memenuhi, namun dari segi pengaturan terhadap industri

\footnotetext{
18 Roem Topatimasang, Kretek Kajian Ekonomi, Hal 68; Indonesia Berdikari, Jogyakarta, 2010.
} 
rokok tidak terlihat adanya dukungan. Dari segi substansi sendiri, Embrio pengekangan industri rokok termasuk Kretek Berawal dari Undang Undang Nomor 36 Tahun 2009 tentang kesehatan di Pasal 113 yang berbunyi sebagai berikut :

(1) Pengamanan penggunaan bahan yang mengandung zat adiktif diarahkan agar tidak mengganggu dan membahayakan kesehatan perseorangan, keluarga, masyarakat, dan lingkungan.

(2) Zat adiktif sebagaimana dimaksud pada ayat (1) meliputi tembakau, produk yang mengandung tembakau, padat, cairan, dan gas yang bersifat adiktif yang penggunaannya dapat menimbulkan kerugian bagi dirinya dan/atau masyarakat sekelilingnya.

(3) Produksi, peredaran, dan penggunaan bahan yang mengandung zat adiktif harus memenuhi standar dan/atau persyaratan yang ditetapkan.

Undang Undang yang kemudian diatur lebih lanjut dalam PP no.109 Tahun 2012 sebagai peraturan operasionalnya ini yang kemudian menjadi ujung tombak kegiatan anti rokok.

Hal yang cukup memukul industri rokok terutama industri Kretek adalah pemberian Ketentuan ambang batas tar dalam rokok. Ketentuan ini memberatkan industri Kretek karena Eugenol, kadar yang terkandung dalam cengkeh juga dikategorikan sebagai tar meskipun tidak memiliki zat yang bersifat karsinogen. Dikategorikannya Eugenol sebagai tar membuat Kretek di posisi yang terpojok dan menguntungkan industri rokok putih yang sepenuhnya menggunakan tembakau. Kondisi ini sangat ironis karena peraturan yang ada seolah mendukung rokok putih yang tidak mengandung Eugenol sehingga kadar tar yang terkandung di dalamnya masih bisa dikontrol.

Substansi hukum yang dikeluarkan oleh lembaga legislatif yang mengekang pergerakan Kretek di Indonesia juga membuat struktur lainnya, terutama lembaga eksekutif dalam menegakkan peraturan juga tidak memihak Kretek sebasgaimana dapat dilihat pada pengenaan cukai pada Kretek yang tentunya lebih tinggi karena kadar tar yang lebih tinggi. Ketentuan dalam Undang Undang kesehatan ini juga membuat kementerian berlomba untuk ikut serta dalam "kampanye anti rokok"19.

Bentuk keikutsertaan ini dapat dilihat pada kementerian perindustrian dimana Untuk industri hasil tembakau, berdasarkan Pasal 4 poin (3) Permenperin nomor 64 Tahun 2014 diwajibkan memiliki pabrik dengan luas minimal 200 meter persegi dan berdekatan langsung dengan dengan jalan raya serta mudah diakses. Ketentuan ini cukup menyulitkan industri rokok terutama industri Kretek tangan yang sebagian

\footnotetext{
19 Kampanye anti rokok dunia sudah dimulai semenjak penelitian penelitian anti rokok seperti yang ditemukan Robert dan Rosalind tentang bahaya rokok. Robert A. Levy And Rosalind B.Marimont, Lies, Damned Lies,\& 400,000 SmokingRelated Deaths, Jurnal, Dimuat Dalam Majalah Regulation Vol.21,No.4,1998
} 
besar merupakan industri kecil dan masih banyak yang belum bekerja sama dengan industri besar. Ketentuan luas pabrik ini merupakan kelanjutan dari ketentuan Pasal 3 ayat (3) Peraturan Menteri Keuangan No 200/PMK.04/2008 sebelumnya. Aturan dari kementerian keuangan ini membuat 93 pabrik rokok yang ada di Kudus dicabut ijin usahanya karena tidak bisa memenuhi ketentuan luas pabrik yang diberikan. ${ }^{20}$

Dari segi Struktur hukum yang meliputi lembaga pemerintah yang bersifat eksekutif, yudikatif dan legislatif. Dalam kaitannya dengan potensi Kretek sebagai Indikasi Geografis maka tentu erat hubungannya dengan peranan lembaga lembaga pemerintah baik eksekutif, yudikatif dan legislatif dalam melindungi Kretek. Dalam hal eksekutif dan legislatif misalnya, penulis akan mencoba mengaitkan dengan pemerintah Kudus.

Dalam wawancara dengan bapak Yosi dari sub bagian hukum pemerintah Kabupaten Kudus, terkait ketentuan Pasal 3 ayat (3) Peraturan Menteri Keuangan No 200/PMK.04/2008 yang mewajibkan pengusaha rokok untuk memiliki pabrik dengan luas minimal 200 meter, hal ini tentu saja mempersulit pengusaha kecil yang sebagian besar industri rumahan. Menanggapi hal tersebut maka

\footnotetext{
20 Http://Kabar24.Bisnis.Com/Read/20120208/78/63266/IzinUsaha-93-Pabrik-Rokok-Dicabut Diakses Pada 23 November 2015.
}

pemerintah Kabupaten Kudus menangulanginya dengan mengeluarkan Peraturan Bupati Kudus Nomor 7 Tahun 2011 tentang pengelolaan lingkungan industri kecil industri hasil tembakau ( LIK IHT ) dan gedung pertemuan industri rokok serta pelayanan pengujian tar dan nikotin di Kabupaten Kudus.

LIK IHT merupakan pabrik sumbangan pemerintah Kudus dari DBHCHT dimana disediakan 10 pabrik yang bisa disewa dengan biaya 4 juta rupiah per Tahun selama maksimal 5 Tahun. Adanya upaya perlindungan dari pemerintah Kabupaten Kudus akan industri Kreteknya sudah menjadi bukti kekooperatifan dari struktur hukum dalam perlindungan Kretek.

Struktur hukum, bekerja tidak berdiri sendiri, ia terkait satu sama lain baik kultur hukum dan juga terpengaruh dari unsur substansi hukum yang dalam hal ini adalah kepanjangan tangan dari dari Undang Undang Nomor 36 Tahun 2009 tentang kesehatan Pasal 113 sehingga instansi pemerintah yang bertanggung jawab seperti dirjen bea dan cukai yang ada dibawah kementerian keuangan, kementerian perindustrian berkewajiban untuk meneruskan aturan tersebut. meneruskan disini kemudian ditafsirkan menjadi merestriksi seperti yang dilakukan oleh kementerian perindustrian atau menafsirkannya dengan tidak mengesampingkan peraturan yang sejajar dengannya seperti perlindungan terhadap 
Jurnal Law Reform

Volume 12, Nomor 2, Tahun 2016
Program Studi Magister Ilmu Hukum

Fakultas Hukum Universitas Diponegoro industri UMKM sebagaimana yang dilakukan pemerintah Kabupaten Kudus.

Poin ketiga dan yang terakhir dari teori Friedman yakni budaya hukum. ia merupakan pandangan, kebiasaan maupun perilaku dari masyarakat mengenai pemikiran nilai nilai dan pengharapan dari sistem hukum yang berlaku, yang artinya budaya hukum ialah iklim dari pemikiran sosial tentang bagaimana hukum itu diaplikasikan, dilanggar dan dilaksanakan. Cerminan dari poin ketiga ini sebagaimana dapat dilihat pada penjabaran penulis tentang kebudayaan Kretek.

\section{B. Implikasi Perlindungan Kretek Sebagai Indikasi Geografis}

1. Implikasi Pada Bidang Ekonomi

Data dari Tobacco Atlas menyebutkan bahwa rokok memiskinkan karena dana yang seharusnya dipakai untuk hal hal yang produktif malah dipakai untuk mengkonsumsi rokok dan menurut Tobacco Atlas juga di negara Tanzania misalnya, menghabiskan 40 juta dolar setiap Tahunnya untuk pengobatan kanker dan konsumsi tembakau mengakibatkan setidaknya 15 juta penduduk India miskin.

Hendaknya pernyataan tersebut perlu ditelaah lebih lanjut karena sebagaimana yang telah penulis jelaskan sebelumnya bahwa tidak sepenuhnya kanker terjadi karena rokok. Sama halnya dengan tidak semua kemiskinan terjadi karena rokok karena Ada banyak faktor yang menyebabkan orang miskin seperti kurangnya lapangan pekerjaan, mental yang lemah dan lain lain.

Satu fakta yang pasti yakni apabila merokok memang penyebab utama penyakit penyakit seperti jantung dan menyebabkan adiksi yang pada ujungnya memperlemah tenaga kerja. Di Indonesia terdapat 58.750.592 orang perokok berdasar data terakhir riset kesehatan dasar $2013^{21}$ dan 225.161.640.007 batang rokok dibakar setiap Tahunnya. Jika harga 1 batang rokok Rp 1.000, maka uang yang dikeluarkan lebih dari 225 trilyun Rupiah. Pertanyaannya apakah Indonesia miskin ? tidak. Karena ada pajak cukai yang dibebankan kepada industri rokok yang kemudian dimanfaatkan untuk kepentingan negara dan faktanya cukai ini merupakan penyumbang dana negara yang cukup besar.

\section{Implikasi Pada Bidang Sosial}

Implikasi perlindungan Kretek sebagai indikais geografis terhadap bidang sosial tentunya yang pertama kali muncul adalah euforia masyarakat karena Kretek, atau secara garis besar rokok yang selama ini erat dengan citra buruknya tiba tiba menjadi

\footnotetext{
${ }^{21 H t t p: / / H e a l t h . K o m p a s . C o m / R e a d / 2015 / 06 / 03 / 110000223 / J u ~}$ mlah.Perokok.Indonesia.10.Kali.Lipat.Penduduk.Singapura Diakses Pada 24 November 2015.
} 
Jurnal Law Reform

Volume 12, Nomor 2, Tahun 2016
Program Studi Magister Ilmu Hukum Fakultas Hukum Universitas Diponegoro produk andalan kabupaten Kudus tentunya meninbulkan kontroversi sehingga Regulasi dan peran aktif dari pemerintah berperan penting terhadap masyarakat karena walaupun negara Indonesia adalah negara demokrasi dimana kedaulatan tertinggi ada pada tangan rakyat, peran pemerintah juga penting.

Peran penting pemerintah disini penting karena aturan bisa membentuk sebuah pemahaman baru pada masyarakat sebagaimana teori dari roscoe pound bahwa tugas hukum adalah alat rekayasa sosial ( a tool of social engineering ) yang merekayasa masyarakat supaya mendapat tujuan yang diharapkan. dengan catatan tidak menganggu kesehatan maupun hak orang lain sehingga pengaturan ruang khusus merokok dan larangan pada ibu hamil dan anak dibawah umur tetap harus ditegakkan 22

Satu lagi poin penting yang perlu diketahui dari implikasi perlindungan Kretek sebagai indikasi geogafis yakni apabila dengan menggunakan aturan indikasi geografis sekarang ini, maka yang mendapat perlindungan indikasi geografis hanya pengrajin yang berada di Kudus, lalu bagaimana dengan pengrajin diluar Kudus ?

Tujuan sebenarnya dari Indikasi Geografis adalah untuk melindungi reputasi,

\footnotetext{
22 lbid.
}

kualitas dan karakteristik dari produk yang dimaksud dan perlu ditambahkan bersifat nasional. Dengan adanya perlindungan Indikasi Geografis maka produk tersebut menjadi sulit ditiru oleh negara lain seperti Champagne yang tidak hanya erat dengan daerah Champagne namun juga negara prancis.

Prinsip perlindungan indikasi geografis inilah yang dimaksud penulis menjadi cara yang efisien untuk menangani upaya pencurian budaya Kretek seperti yang dilakukan Marlboro dengan produknya Marlboro Kretek Mint di Meksiko dan hal inilah juga yang disebut penulis sebagai Indikasi Geografis yang bercirikan nasionalisme.

3. Implikasi Pada Bidang Hukum

Menjadikan Kretek sebagai produk Indikasi Geografis Kudus sama saja dengan menjadikan Kretek sebagai produk andalan Kabupaten Kudus yang berarti pemerintah kabupaten wajib melestarikan pengetahuan tentang Kretek dan mendukung industri Kretek.

Tindakan melestarikan pengetahuan tentang Kretek sendiri sudah dilakukan pemerintah Kudus sebagaimana dapat dilihat dari didirikannya musium Kretek Kudus namun terkait dengan upaya untuk mendukung industri Kretek Kudus nampaknya masih menjadi hal yang sulit. 
Jurnal Law Reform

Volume 12, Nomor 2, Tahun 2016
Program Studi Magister Ilmu Hukum

Fakultas Hukum Universitas Diponegoro
Bentuk dukungan dari pemerintah Kabupaten Kudus tentunya dalam bentuk mengenalkan produk unggulan Kretek kepada masyarakat dan hal ini tentunya akan menjadi polemik karena tindakan mengenalkan Kretek pada masyarakat akan bertabrakan langsung dengan ketentuan pada Pasal 27 PP nomor 109 Tahun 2012.

Menanggapi hal ini penulis mencoba untuk menabrakkannya dengan ketentuan Indikasi Geografis. Di dalam aturan hukum dikenal adanya Hierarki Hukum²3.yakni suatu strata aturan hukum yang berlaku dan di dalam hierarki tersebut Undang Undang dasar berada di strata yang lebih tinggi daripada Undang Undang atapun peraturan pemerintah yang ada di bawahnya.

PP no 109 Tahun 2012 memang setara dengan PP no 51 Tahun 2007 demikian bila melihat Undang Undang diatasnya dapat dilihat bahwa Undang Undang Nomor 36 Tahun 2009 mengatur mengenai zat yang bersifat adiktif yang kemudian dijabarkan pada Pasal 113 bahwa zat adiktif tersebut meliputi hasil tembakau. Indikasi geografis juga serupa, ia diatur dengan Undang Undang Nomor 15 Tahun 2001 tentang merek yang kemudian diatur oleh Peraturan pemerintah nomor 51 Tahun

\footnotetext{
${ }^{23}$ Bab III Pasal 7 Ayat (1) UU No 12 Tahun 2011 Tentang Pembentukan Peraturan perundang undangan
}

2007. Namun ada dua hal yang perlu diperhatikan disini.

Pertama dari segi aturan yang setara. Undang Undang kesehatan hanya memberikan kewenangan kepada aturan dibawahnya dalam hal ini PP no 19 Tahun 2012 untuk diarahkan agar tidak mengganggu dan membahayakan kesehatan perseorangan, keluarga, masyarakat, dan lingkungan. Namun pada kenyataannya aturan yang ada di dalam PP ini mengatur melebihi kewenangan yang diberikan yakni pembatasan iklan ( O ver-Authority) sehingga apabila melihat aturan yang berada diatasnya yakni dalam strata Undang Undang maka Indikasi Geografis lebih unggul karena ia diatur perlindungannya di dalam Undang Undang 15 Tahun 2001 dan aturan pelaksanannya yakni PP no 51 Tahun 2007 tidak melebihi kewenangan yang diberikan Undang Undang sehingga dalam pengaturan memperkenalkan produk Kretek ke masyarakat apabila Kretek menjadi produk Indikasi Geografis Kabupaten Kudus masih dapat diperbolehkan menurut Undang Undang.

Poin kedua yang memperkuat penjelasan dari poin pertama tadi ialah peraturan yang ada diatas kedua Undang Undang tersebut yakni Undang Undang dasar. Di dalam Undang Undang dasar ada dua Pasal yang mendukung keberadaan 
Jurnal Law Reform

Volume 12, Nomor 2, Tahun 2016
Program Studi Magister Ilmu Hukum Fakultas Hukum Universitas Diponegoro industri Kretek di Indonesia yakni : Pasal 27 ayat (2) dimana Tiap tiap warga negara berhak atas pekerjaan dan penghidupan yang layak bagi kemanusiaan. Dan Pasal 32 ayat (1) dimana negara memajukan kebudayaan nasional Indonesia di tengah peradaban dunia dengan menjamin kebebasan masyarakat dalam memelihara dalam mengembangkan nilai nilai budayanya.

Pasal 27 ayat (2) dan Pasal 32 ayat (1) UUD dapat menjadi embrio perlindungan Kretek baik sebagai produk Indikasi Geografis Kudus. Pasal 27 ayat (2) misalnya. Industri Kretek merupakan salah satu industri yang banyak menyerap tenaga kerja maka dari itu tenaga kerja yang ada di dalamnya harus mendapat perlindungan yang layak tidak dibeda bedakan dengan industri lainnya dengan aturan seperti Pasal 4 poin (3) Peraturan menteri perindustrian nomor 64 Tahun 2014 diwajibkan memiliki pabrik dengan luas minimal 200 meter persegi yang memberatkan industri kecil.

Ketentuan dalam Pasal 32 ayat (1) dapat menjadi dasar upaya pemerintah Kabupaten Kudus nantinya apabila Kretek menjadi produk Indikasi Geografis Kudus dalam hal pelestarian pengetahuan tradisional tentang Kretek.

Pasal 27 ayat (2) dan Pasal 32 ayat (1) UUD disebutkan penulis bukan dengan maksud membela Kretek ${ }^{24}$. Penulis dalam membuat tulisan ini berusaha bersikap objektif karena kenyataan di dalam peraturannya memang begitu. Di pihak yang kontra terhadap rokok sendiri ada aturan yang mendukungnya di Undang Undang dasar yakni sebagaimana dapat dilihat pada Pasal $28 \mathrm{H}$ ayat (1) dimana setiap orang berhak hidup sejahtera lahir dan batin, bertempat tinggal, dan mendapatkan lingkungan hidup baik dan sehat serta berhak memperoleh pelayanan kesehatan.

\section{Kesimpulan}

Kesimpulan dari penelitian ini adalah bahwa Kretek memungkinkan menjadi produk Indikasi Geografis karena baik dari segi Sejarah, metode pembuatan maupun Kontrol Kualitas sudah memenuhi persyaratan yang dipersyaratkan berdasarkan Undang Undang Nomor 15 Tahun 2001 dan dalam perkembangannya dimungkinkan juga menjadi Indikasi Geografis nasional atau bahkan Warisan Budaya Indonesia karena sejak ditemukan di Kudus ia sudah menyebar ke penjuru Indonesia.

Perlindungan Kretek sebagai Indikasi Geografis Kudus menimbulkan Implikasi Positif baik pada bidang Ekonomi seperti meningkatnya

\footnotetext{
24 Sebagaimana dapat dilihat pada pendapat Lauren Colby bahwa rokok tidak memiliki hubungan dengan tingkat mortalitas. Lauren Colby, Terjemahan Ronny Hendrawan, In Defense Of Smokers, Hal 44; Indonesia Berdikari, Jakarta 2014.
} 
Jurnal Law Reform

Volume 12, Nomor 2, Tahun 2016
Program Studi Magister Ilmu Hukum

Fakultas Hukum Universitas Diponegoro pemasukan negara dan penyerapan tenaga kerja, di bidang Sosial dimana dapat meluruskan stigma negatif Kretek, dan juga di bidang Hukum dimana Kretek yang dijadikan Indikasi Geografis dapat dijadikan Referensi bagi hasil industri lainnya untuk menjadi produk Indikasi Geografis.

\section{Saran}

1. Kepada DPR terkait Pasal 56 ayat (7) UU Nomor 15 Tahun 2001 yang mengatur mengenai batas perlindungan apabila ciri khas hilang perlu dikaji lagi terutama dalam hal hasil kerajinan dan industri yang sulit memiliki ciri khas yang signifikan karena berdasar pada pemikiran manusia yang pasti dapat berubah entah karena faktor eksternal seperti permintaan pasar atau internal sehingga perlu adanya Pasal yang khusus mengaturnya tersendiri.

2. Kepada DPR terkait PP no. 109 Tahun 2012 yang terlalu Over Authority karena mengatur permasalahan yang berada diluar kesehatan untuk direvisi kembali. Dan terkait Undang Undang Nomor 15 Tahun 2001 tentang merek yang mengatur Indikasi Geografis dan PP nomor 51 Tahun 2007 untuk diamandemen terkait pengaturan kerajinan dan hasil industri yang mengadopsi hukum India misalnya sehingga dapat memenuhi kebutuhan perlindungan kerajinan dan industri potensial di Indonesia.

\section{DAFTAR PUSTAKA}

\section{Literatur}

Bab III Pasal 7 Ayat (1) UU No 12 Tahun 2011 Tentang Pembentukan Peraturan Perundang Undangan

Kesowo, Bambang, 2007, Posisi Dan Arti Penting KI Dalam Perdagangan Internasional; Jakarta: Citra.

Buku Persyaratan Indikasi Geografis Meubel Ukir Jepara, 2010

Atmadja,Edi, Artikel, Hukum Sebagai Sarana Rekayasa Sosial, Radar Lampung, 30 Mei 2012.

Lubis,Efriadi, 2009, Perlindungan Dan

Pemanfaatan Sumber Daya Genetik

Berdasarkan Penerapan Konsep Sovereign

Right Dan Kekayaan Intelektual, Bandung:

Alumni.

Framework Convention On Tobacco Control

Geographical Indications Of Goods

(Registration And Protection) Act, 1995. India

G.C. Clark (1989). "Comparison Of The Inhalation

Toxicity Of Kretek (Clove Cigarette) Smoke

With That Of American Cigarette Smoke. I.

One Day Exposure". Archives Of Toxicology.

Hadari , Nawawi \& Mimi Martini, 1994, Penelitian

Terapan, Yogyakarta.

Lauren, Colby,2014, Terjemahan Ronny

Hendrawan, In Defense Of Smokers, Jakarta: Indonesia Berdikari 
Friedman, Lawrence,1994, American Law, W.W Norton \& Company, London.

Manufacturing \& Investment Around The World: An International Survey Of Factors Affecting Growth \& Performance, ISR Publications/Google Books, revised second edition, 2001.

Richard Posner, Dalam Sanders, Anthony, Posner,2003, Hayek \& The Economic Analysis Of Law, Paper, Hal 1 ; Geogre Mason University, Virginia.

Robert A. Levy And Rosalind B.Marimont, Lies, Damned Lies, \& 400,000 Smoking-Related Deaths, Jurnal, Dimuat Dalam Majalah Regulation Vol.21,No.4,1998

Roem Topatimasang, 2010, Kretek Kajian Ekonomi, Yogyakarta: Indonesia Berdikari.

Ronald Hutapea, 2013, Why Rokok? Tembakau Dan Peradaban Manusia, Jakarta: Bee Media.

\section{Internet}

http://www.Sampoerna.Com/ld_Id/Tobacco_Regula tion/Pages/Tobacco_Taxation_System_In_In donesia.Aspx Diakses Pada 14/08/2015

Melissa Brockley, TED Case Studies Number760, 2004 Pada Http://www1.American.Edu/Ted/TurkishTobacco.Html Diakses Pada 14/08/2015.
Http://www.Pmi.Com/Eng/Our Products/Pages/Our Brands.Aspx Diakses Pada 24 November 2015

Registered GI November 2015 In India, Http://IpIndia.Nic.In/Girlndia/ , Diakses Pada 20 November 2015

Http://Kabar24.Bisnis.Com/Read/20120208/78/632 66/Izin-Usaha-93-Pabrik-Rokok-Dicabut Diakses Pada 23 November 2016.

Http://Health.Kompas.Com/Read/2015/06/03/11000 0223/Jumlah.Perokok.Indonesia.10.Kali.Lipat .Penduduk.Singapura Diakses Pada 24 November 2016 